\title{
BARRIERS TO GENE FLOW IN NATURAL POPULATIONS OF GRASSHOPPERS \\ I. THE BLACK CANYON OF THE GUNNISON RIVER AND ARPHIA CONSPERSA. ${ }^{1}$
}

\author{
By Robert B. Willey and Ruth L. Willey ${ }^{2}$
}

\section{INTRODUCTION.}

The oedipodine grasshopper, Arphia conspersa, is polymorphic for wing color in Colorado. This feature may prove useful as a marker for tracing historical patterns of gene flow between populations. The metathoracic wings vary from vermillion through salmon-orange to yellow with several intermediate shades which are almost certainly heterozygous in genotype. Although the known populations of the Colorado Front Range are all polychromatic (Gordon Alexander, personal communcation), populations in the Gunnison River Basin on the Western Slope often are monochromatic. For example, those to the south in the foothills of the San Juan Mountains are uniformly yellow as a rule, and those to the north in the Elk and West Elk Mountains are usually salmon-orange. However, near the Gunnison River, which runs west through the center of the basin, there occurs a complex series of populations in various stages of introgression and separation. We wish first to present the case of the Black Canyon of the Gunnison River which presents a striking example of a topographic barrier to gene flow, reminiscent of the cases of the Abert-Kaibab squirrels and other mammals on the north and south rims of the Grand Canyon in Arizona (Allee, et al., 1949, p. 608; Hall and Kelson, 1959).

The Black Canyon. The canyon is located in the west central part of Colorado, about 60 miles southeast of Grand Junction. It is about 50 miles long, 20 miles of which are included in the Black Canyon National Monument. In forming this deep canyon, the Gunnison River has worn its way vertically through about 2000 feet of hard pre-Cambrian rocks, primarily gneiss and granite. The river

\footnotetext{
${ }^{1}$ Research conducted at the Rocky Mountain Biological Laboratory, Crested Butte, Colorado.

${ }^{2}$ Address: Department of Biological Sciences, University of Illinois at Chicago Circle, Chicago, 60680.

Manuscript received by the editor December 31, 1966.

Explanation of Plate 5

Southeastward view of the North and South Rims of the Black Canyon from Fruitland Mesa. Grizzly Gulch (locality \#23) is the valley in the foreground, Coffee Pot Hill and Poverty Mesa are in the upper left background.
} 


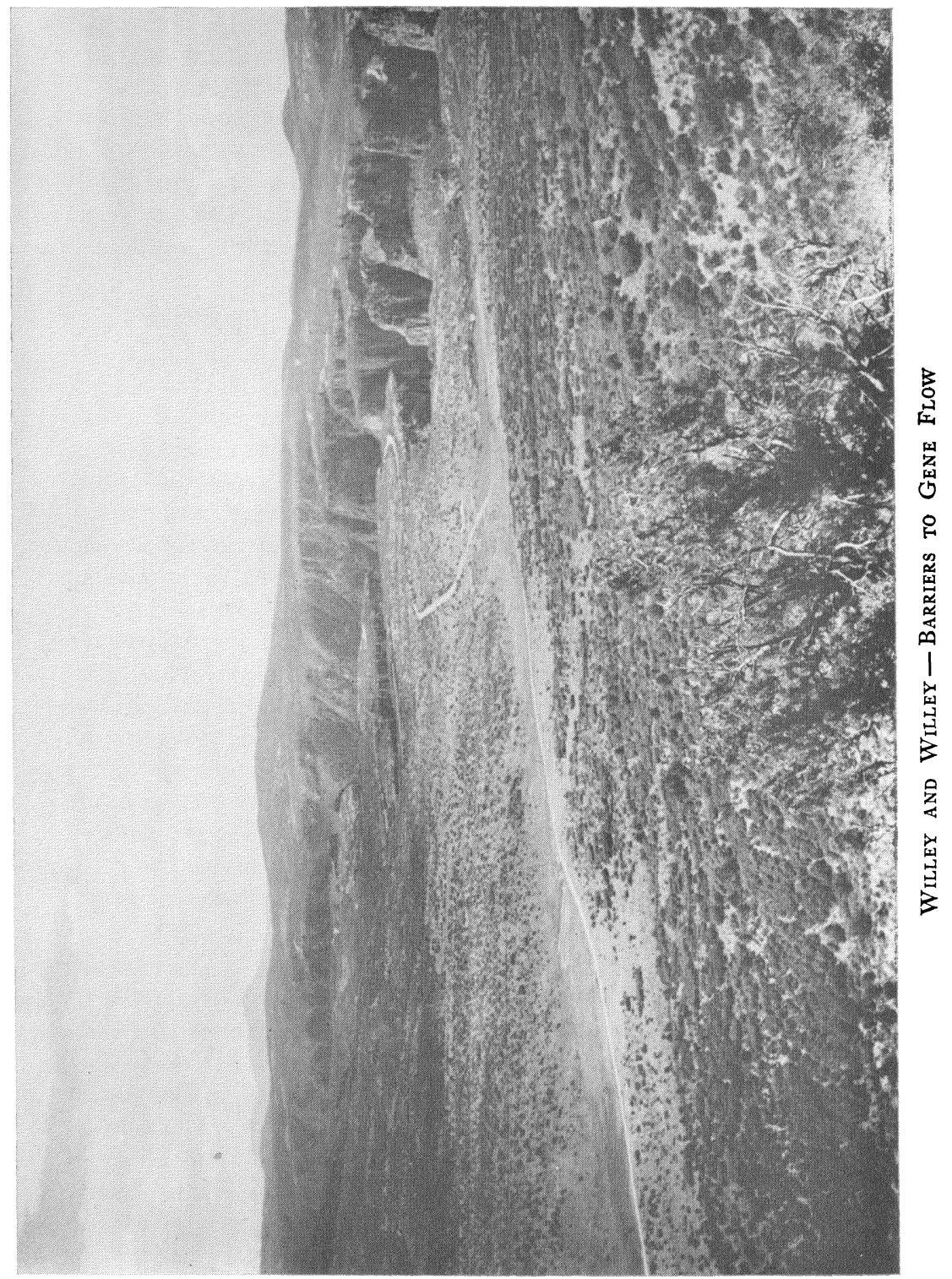


has the unusually steep average gradient of 43 feet per mile for the 50 miles length of the canyon. Within the monument boundaries the rate of fall is 95 feet per mile - all without a major falls. The downcutting power of the river is so great that the minor tributaries flowing from the rims generally have not been able to keep pace and are left as hanging tributaries or narrow precipitous gulches. Only a few actually reach the river. The canyon is probably not more than two million years old, representing an average cutting speed of one foot per thousand years.

Several historical accidents contributed to form the Black Canyon (Hansen, I 962) : I) the Gunnison River was already cutting through soft overlying lava flows when the Gunnison Uplift gradually rose for a second time. The river was committed to the channel and was just able to keep cutting through the hard basement material in pace with the rising land. 2) The rock down-stream from the upthrust was much softer, thus maintaining the river's cutting gradient through the canyon. 3) The water catchment capability of the mesas which were formed by the upthrust is meager and most of the streams are dry except for a month during the spring snow melt. Thus side canyon erosion is negligible or directed away from the canyon rims. 4) Fractures and joints in the rock are vertical or, in many places, virtually non-existent. Lateral erosion then results in perpendicular sheering and nearly vertical walls. All of these factors contribute to the formation of a canyon with an average depth equal to or greater than its average width, with cliffs falling sheer IOOO-2000 feet to the river below. At the Narrows the depth is $175^{\circ}$ feet, the distance between the rims is I IOO feet, and the width of the canyon at the river is 40 feet, a depth-to-width ratio unmatched by any other major North American canyon.

The mesa formed by this block upthrust and split by the Gunnison River averages 8000 feet in elevation \pm 300 feet, whereas the surrounding valleys to the south, west and north average less than 6000 feet. The vegetation on the mesa top is characterized by a chaparral composed of Gambel's oak, service berry, mountain mahogany and isolated stands of Utah juniper and pinyon pine. Grassy openings are scattered through the thick brush and the populations of Arphia conspersa reach their greatest density in these open areas. Average rainfall is estimated from records kept at the Monument Headquarters on the South Rim to be about ro inches per year, at least half of it falling as snow during the winter. For the past three years at Monument Headquarters the prevailing winds at I :OO P.M. have been south to northwest, with the mode in the west and south- 
west. However, this varies from year to year with too many variable factors involved to be very meaningful. There is no observable difference in vegetation or climate between the two rims which also are nearly identical in elevation.

To the south, west and north the area is surrounded by arid barren lands ("Dobe Hills") and irrigated farms, areas in which $A$. conspersa has not been found. The primary Gunnison uplift continues to the continental divide on the east, however, with grasslands and forest openings favorable to maintaining large populations of the species.

Arphia conspersa. This species is characteristic of the western Great Plains and foot hills of both slopes of the Rocky Mountains from Northern Mexico to the Canadian plains provinces. In all of its range it is springbrooded with the nymphs overwintering and emerging as adults a few weeks after the snow melts or at the onset of warm weather. Therefore the peak of population activity is altitude and latitude dependent. At the Black Canyon the peak in "typical" years occurs probably in late May at 6000 feet and is delayed until mid-June or later at 8000 feet on the rims of the canyon. The phenology is dependent on the "lateness" or "earliness" of the season as well. The population at 8000 fcet reached its peak during the second week of June in 1966 and the last week of June in 1965 - a heavy snow year.

Our studies of this species' behavior are not yet published; therefore a brief summary of its biology is in order. Arphia conspersa is a remarkably sedentary species, considering its flight capabilities and its active behavior. Its low vagility (Allee et al, 1949, p. 213) is probably caused in part by complex social interactions which include short spontaneous flights, primarily by the males, only 6 to 10 feet in length. During these flights the wings make a buzzing sound or crepitation. Adult males and females tend to gather in interacting sub-deme groups. The size of each cluster is seldom more than IoO to 200 feet in radius regardless of the extent of the suitable habitat. Seldom does the density of the male population reach 6o per acre even in the clusters; Io to 20 males per acre in suitable habitat is the usual population. Females are more sedentary and seldom fly except as young adults.

Cloudy, windy weather suppresses flight activity markedly. These insects often become so immobile that they can be picked up by hand - if they can be found. Arphia is a relatively small grasshopper and there is little heat storage in its body. Slight meteorological changes register quickly on the activity of the population. At air velocities 
of about 6 miles per hour at three feet above the ground, we have consistently observed cessation of spontaneous flights and at ten miles per hour cessation of $90 \%$ of the escape flights. The insects creep into rock crevices and into clumps of grass, becoming difficult to dislodge. $A$. conspersa is reluctant also to fly more than a few feet over a radically changed substrate such as an asphalt road. A typical maneuver of this insect is to curve back and land at the grassy side, even if it means coming back to the investigator. Stronger fliers, such as Xanthippus, Cratypedes, and Circotettix show no reluctance to fly over such changes in substrate.

Long escape flights of several hundred feet with the wind will occur in response to strongly disturbing stimuli. These escape flights are silent and can occur at lower temperatures than the normal lower threshold of the spontaneous flights. However, our studies indicate that males seldom move more than two hundred feet and tend to stay within the area of the sub-deme cluster. Long escape flights are rare and usually occur in response to unusual harassment as by the investigator. On the other hand, spontaneous crepitating flights by the males are frequent during the four-week mating and egg-laying season. As the population ages, however, males show decreasing persistence in courtship and make fewer flights. Whatever dispersion of $A$. conspersa by flight occurs, then, is restricted to a relatively short session in the Spring and may include the very infrequent escape flights of males and young females. Nothing is known about the vagility of nymphs.

The preferred food plants of $A$. conspersa are narrow-leaved grasses such as Poa palustris; broad-leaved forbs are not eaten even in captivity unless the insects are starving. Bare spaces between bunches of grass appear necessary for courtship interactions and moist ground nearby tends to lengthen the life span of the population by several weeks. However, the species is seldom found in tall grass meadow, on bare rock slopes, in thick forest or dense chaparral unless there are short-grass openings of at least an acre in area. Irrigated farm land with luxuriant meadows is likely to have $A$. conspersa only along the unirrigated road sides or in low density on rocky knolls which have much of the original grassland intact. Thus, although it is a common and wide-spread species, it tends to have rather restricted habitat preferences and, owing to its social behavior, tends to settle

Explanation of Plate 6

The Gunnison River within the Black Canyon viewed from Pulpit Rock on the South Rim. The rim walls rise $1700 \mathrm{ft}$ above the river at this point. at this point. 


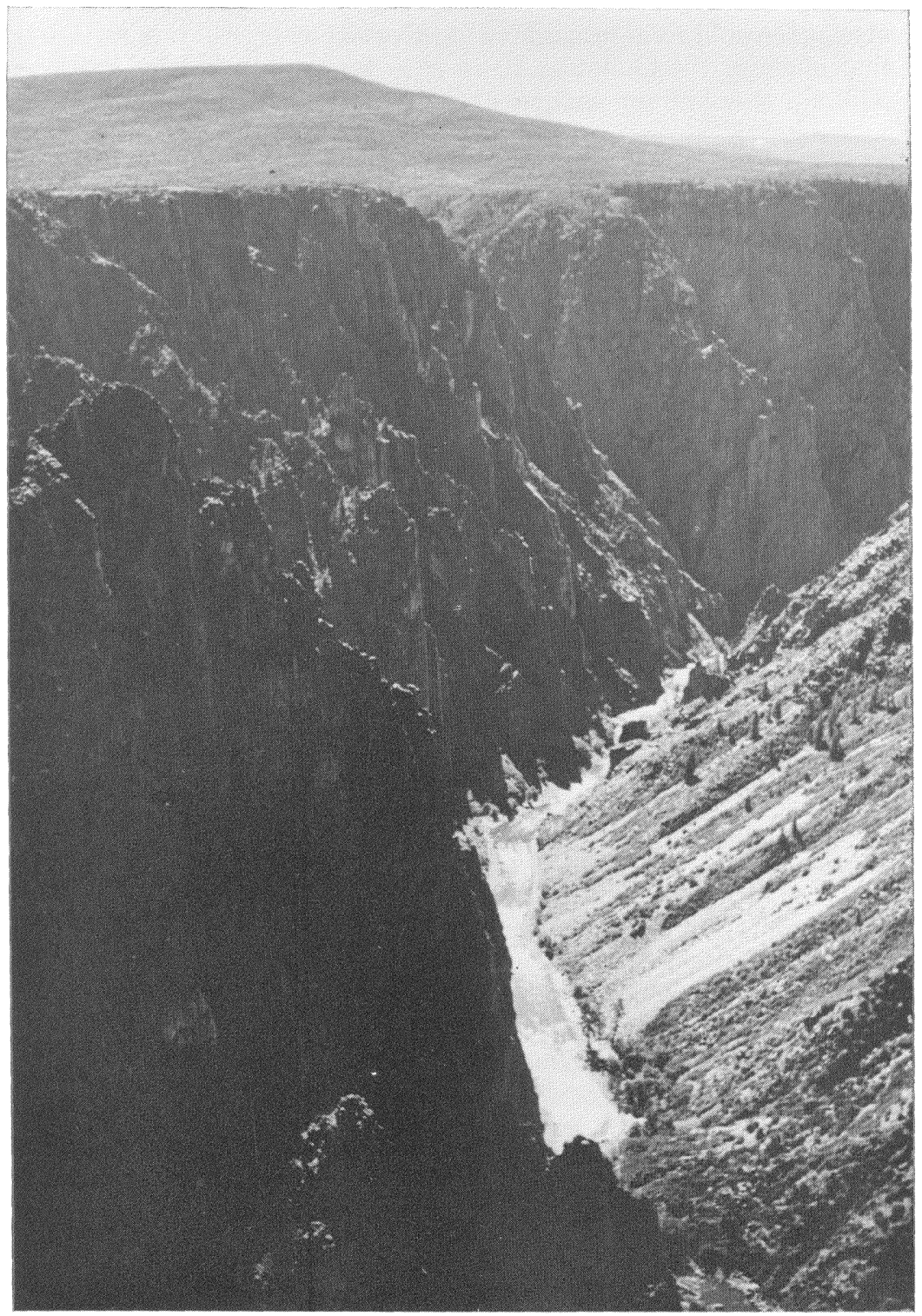

Willey and Willey - Barriers to Gene Flow 
in small demes and clusters isolated by several sorts of barriers, some of which would seem insignificant to a casual observer. It is fortunate that much of the Gunnison Basin is so far undisturbed by man and allows a base line for analysis of geographic variation in this species.

\section{Methods}

The basic requirement was to make a large enough sample to be reasonably accurate within the limited available time and yet not disturb the composition of the next generation. Therefore capture sampling methods were not used except for special purposes. In each locality we tried to count over 200 individuals on an area of 30 to 50 acres. The sex ratio observed was typically greater than Io males to one female due to the lubberly behavior of the females. We estimated the average density as Io to 20 males per acre, so the sampled population was between $20 \%$ and $30 \%$ of the total male population of the sampled area. Each observer selected a different sector and walked a non-repeating path through likely areas of heavy grasshopper concentration. As the insects made their escape flights or spontaneous social flights, the color of the wings was classed as either orange or yellow, since intermediate shades are difficult to distinguish from orange during flight. The landing place of each individual was noted and if an insect subsequently flew up within a foot of that area it was ignored, unless the color were the opposite shade. If there was any doubt as to whether an insect was an independent observation, it was not counted. Since the average density was about 10-20 per acre and the greatest density was about 6o per acie in isolated clusters, we had no difficulty in tracing individuals.

One difficulty was noted early in the study; often the orange wings would not be visible because of shadow or peculiar angles and the yellow abdomen of the male would flash brightly instead. For this reason, any indefinite yellow-flashing individual would be forced to fly again. A second chance of error in sampling is the probability that the rarer color is counted more accurately than the dominant color. If a counted grasshopper should land near another of the same color and only the second one should fly up again, by our rules it would not be counted, whereas one of a different color would be counted. Therefore, the wing-color variant which is rare in the population could conceivably be of a lower frequency than actually recorded. A third difficulty encountered was the presence of another species of springbrooded oedipodine, Xanthippus corallipes, whose wings typically flash lemon-yellow in flight. Pink-winged variants occur rarely in these populations. Experienced observers can easily 
distinguish the two species in flight by shade differences, banding of the wing, and flight behavior. Here again, any individuals which could not be checked with certainty were not counted. All the observers were experienced enough to be accurate by the time they started work on these localities. Later in the season, several other bandwing species begin to appear, but they are all easily distinguished in flight from $A$. conspersa.

The most productive time for counting the population was between Io $A M$ and 4 PM on clear warm days. Since the peak for each population lasts only two weeks, and three or four observers take an average of $I \frac{1}{2}$ hours to count a sample of 200 , time is an important factor.

A second method was to collect about 50 specimens as nearly at random as possible. This usually took longer than merely counting 200 in the field and required additional curatorial time. However, we did collect from large populations and in this way we could check on the frequency of various shades of presumed heterozygotes. Recently, laboratory breeding of individuals from selected localities has proved successful, and the genetic analysis when completed will be reported later.

\section{Results and Discussion.}

The accompanying maps and table (figs. I and 2, and plate 7 ) show the wing-color proportions of each sampled locality between Sapinero and Green Mountain Reservoir. The most striking difference between the populations of the North and South Rims occurs within the National Monument itself. In more than three years of intensive sampling, populations of the monument's North Rim have never been observed to produce a yellow-winged individual $(n=1355)$, whereas the South Rim's population varies in a cline from $<65 \%$ yellow in the west to $>90 \%$ yellow at the eastern boundary.

First we shall consider the physical properties of the canyon rims. On both the South Rim and North Rim the grass habitat is quite discontinuous. Grassy openings in the chaparral are often separated by several hundred yards of dense brush. In this way, the rim populations are broken up into semi-isolated units which show sharp clinal variation which is less dependent on distance than on the density and impenetrable nature of the chaparral barrier. For example, the populations on the South Rim (fig. I) along the relatively continuous grassy areas locality from Sunset View (\# 3) to Gunnison Point $(\# 6)$, a surface distance of three miles, are stabilized at $33 \%$ to $36 \%$ orange. At the campground $(\# 7)$ the proportions vary from 


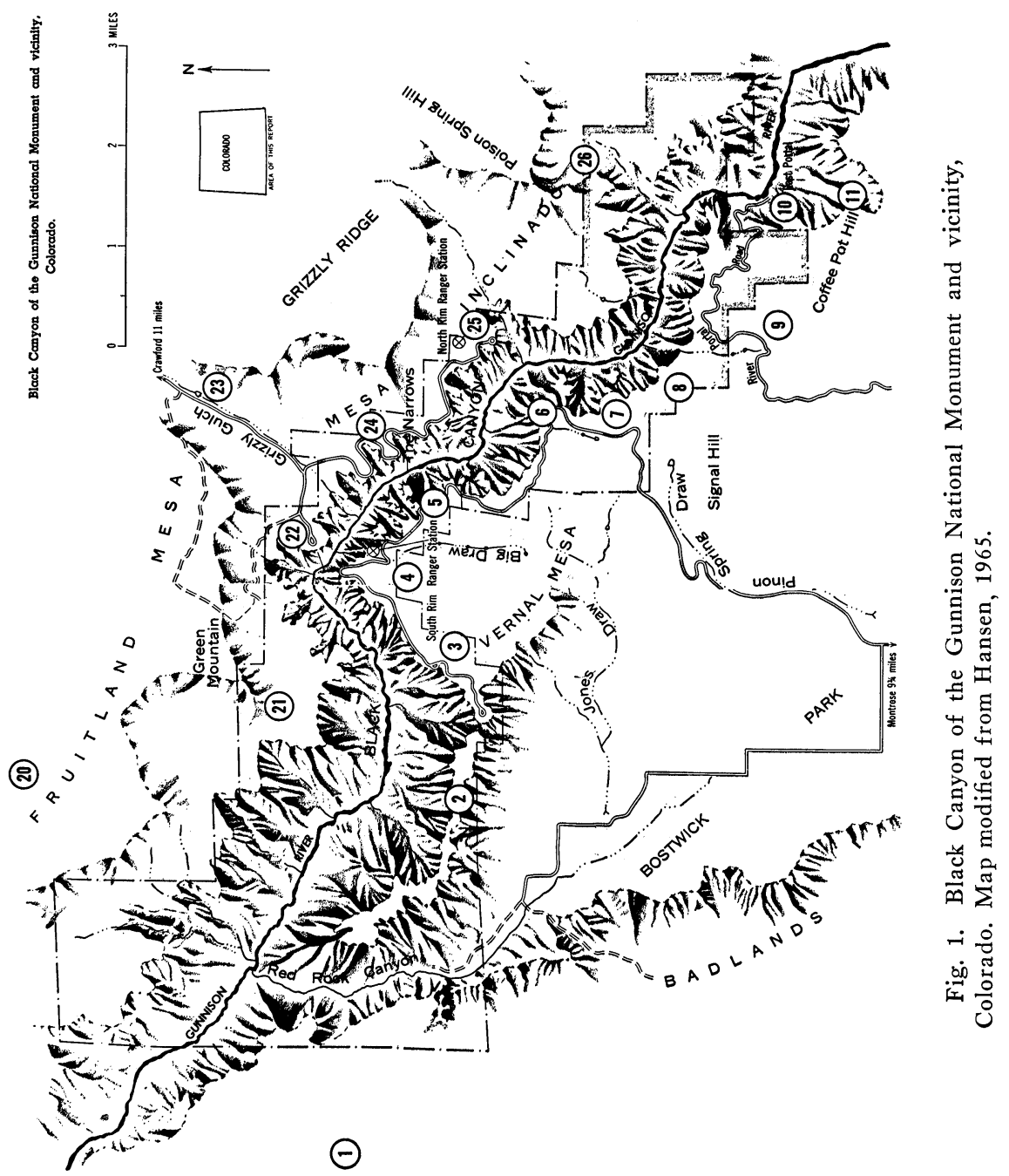


$2 \mathrm{I}$ to $29 \%$. Then in a distance of only $\mathrm{I} 1 / 2$ miles across dense chaparral the proportions drop to $6 \%$ orange $(n=187)$ at the head of East Portal Canyon (\#9). Late in the season of 1966 , we sampled the area between these two localities and found only three openings in the chaparral ranging from about 5 to Io acres each. The proportions were about IO\% orange in each habitat (total $n=87$, locality \#8). Recently, trails six feet wide through the brush have been cleared to allow cattle access to the grass. Several Arphia were found on these trails between the meadows. Chaparral in this area is 6 to $8 \mathrm{ft}$ tall and impenetrable to man. It is clearly a major factor in the isolation of $A$. conspersa demes.

Continuing eastward along the South Rim (plate 7 ), the proportions of orange diminish gradually to zero on Fitzpatrick Mesa (\# I6). Then on the eastern portion of the mesa (\#I7), orange individuals appear in small numbers. The proportions rapidly increase eastward to Sapinero $(\# 40)$, where the Black Canyon begins. This population was about $85 \%$ orange and showed the influence of a major orange-winged population continuous with the Elk Mountain centers north of the river. The presence of a large isolated yellow population in the Soap Creek Valley north of Sapinero and the Gunnison River illustrates the complexity of the geographic variation in the eastern populations. On Black Mesa a line of aspenspruce forest 2 miles wide separates the eastern yellow outpost (locality \# 32, $28 \%$ orange, $\mathrm{n}=\mathrm{I} 26$ ) from the north-western orangewinged populations (at \# $31,100 \%$ orange, $n=108$ ) as effectively as the Black Canyon does.

Westward along the North Rim of the canyon, the orange populations afford less obvious clinal variation than is true with the South Rim populations. The eastern demes near the zone of contact with the Soap Creek yellow, though counted by sight transect as all orange or with less than $\mathrm{I} \%$ yellow, include some lighter orange individuals - presumably heterozygotes. Collections show a complex phenotype series which so far has defied biometric analysis. Genetic analysis of each phenotype is now underway in laboratory matings.

Turning to the canyon itself, only three areas seem to have suitable and continuous habitat down to the river on both sides to afford a crossing point. These points are, west to east, Red Rock Canyon and an unnamed canyon (\# I) just west of it, East Portal (\# IO), and Blue Creek. West of Red Rock Canyon the southern population is uniformly orange $(n=86)$ and may be the source of the orange 


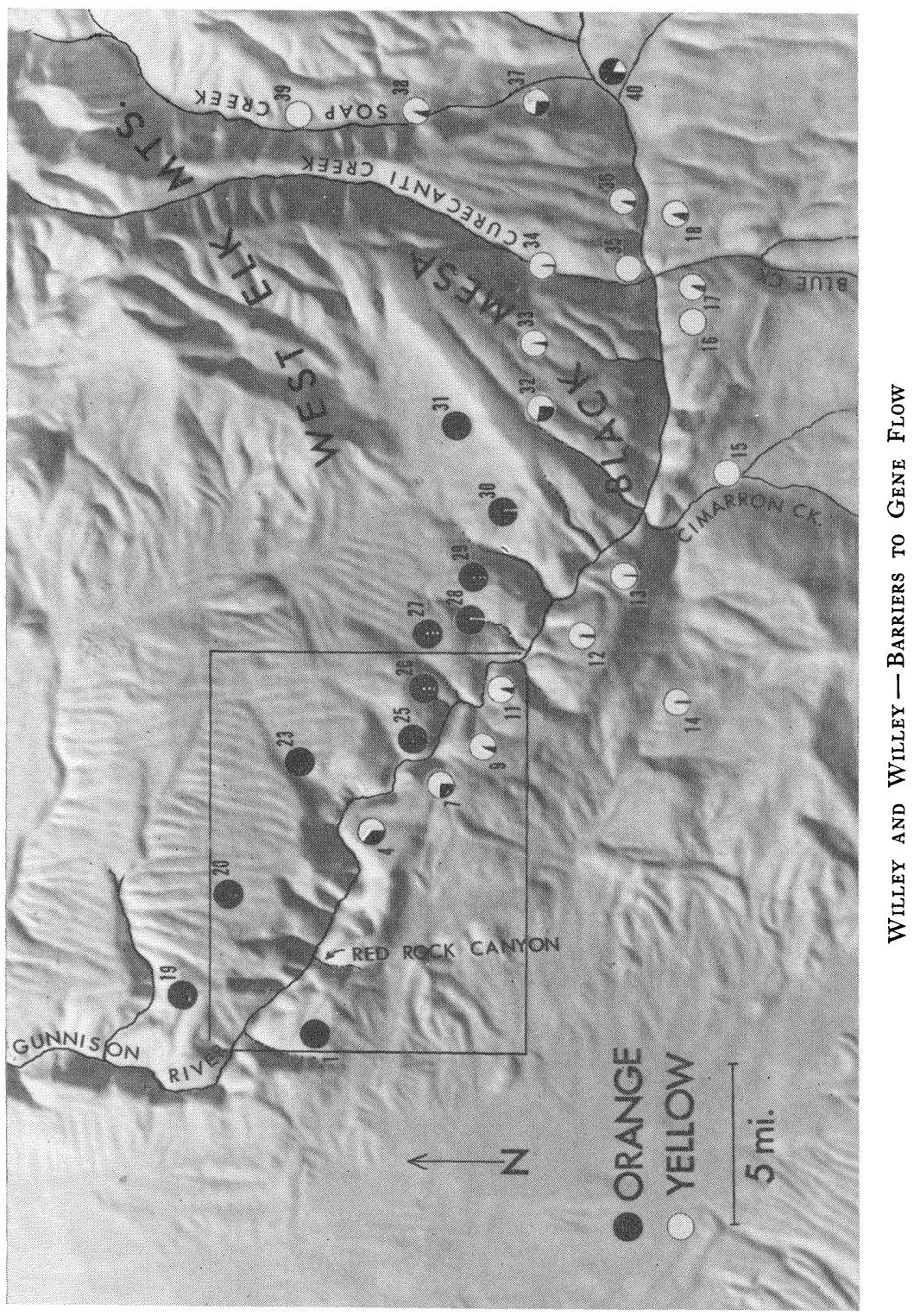


variants of the eastern South Rim demes. Red Rock Canyon ${ }^{6}$ has so far been inaccessible to us at the proper season. The East Portal deme $^{6}$ at the river's edge has its peak too early in June for researchers with academic responsibilities, but a count of the last survivors on the south side of the river in mid-June, I966, showed Io yellow and 2 orange, whereas a deme at the head of Spring Gulch (\#28) across the river and one mile north-east was $>99 \%$ orange $(n=262)$ and less than a mile south of the river at the head of East Portal Canyon (\#9) the population was $94 \%$ yellow $(n=187)$. The river-edge populations at the confluence of Blue Creek and Curecanti Creek are inaccessible so far because of the seasonal factor and the construction of Morrow Point hydroelectric dam. However, the map (fig. 4) indicates that here, too, is a probable crossing point because of the similarity of population proportions. There is continuity of marginal habitat, also. Undoubtedly there is a strong influx of genes for yellow wing color from Soap Creek Valley, as well.

At all other points we have found gulches, such as Dead Horse Gulch (\#26) on the North Rim, which reach the river with fairly continuous habitat, but the opposite wall rises as a jumble of bare rocks and precipitous cliffs, creating an effective barrier to further movement. The banks of the river are either overgrown with brush, blocked with talus or composed of gravel bars with no grassy openings larger than a few square yards. High water marks $5 \mathrm{ft}$ above the June water level indicate early spring flooding of the banks with accompanying great turbulence, making it unlikely that overwintering nymphs could survive on the infrequent sandy shores of the river.

In addition to the effect of distance and difficult terrain, the effect

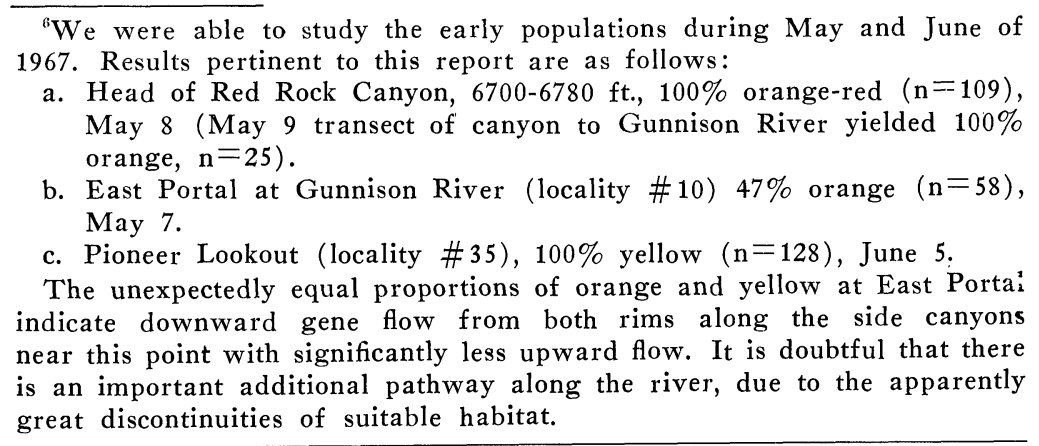

Explanation of Plate 7

The Black Canyon Area. The section within the marked rectangle is shown in greater detail in Fig. 1. Numbers correspond to the locality numbers in the table, Fig. 2. Ideas on format thanks to Wallace Hansen. 
of altitude on the phenology of populations within the canyon is of interest. For example, at the head of East Portal Canyon and nearby Coffee Pot Hill (elevation $8600 \mathrm{ft}$ ), on June I5, I966, the insects were at their reproductive peak with high population density, numerous pairs in copula and constant spontaneous flights. Within the canyon at East Portal (elevation 6500 to $6700 \mathrm{ft}$ ) on June 19, I966, the population was nearly non-existent. The males which were observed seldom flew and several which were captured had worn wings and missing legs. The climatological conditions were essentially identical and were optimal for behavioral interaction. On July 2I, I965, the previous year, the population at the head of East Portal Canyon was clearly senescent, whereas no Arphia could be found below at East Portal. Indeed Trimerotropis sparsa, a summerbrooded oedipodine, was at its peak.

\section{Conclusions}

It is doubtful that significant gene flow in Arphia conspersa occurs across the Black Canyon except at the three isolated points mentioned and these may be quite minimal. If it did, we would have to explain why the North Rim population is so free of the yellow phenotype and the eastern South Rim is so nearly free of the orange phenotype. We should expect the recorded SW winds to carry a winged species across the relatively short aerial distance between the two rims with a resulting admixture of the yellow phenotype in the now completely orange-winged populations of the North Rim. But examination of the data shows that this has not happened to any significant degree. Besides, the behavior of this species is not conducive to transport by wind, since increased velocity of wind suppresses flight activity. As we have seen, persistent chasing can force an Arphia across the road or over a hedge or down a gulch, but such pursuit is an artificial situation which seldom occurs in nature. Nearly constant canyon updrafts definitely prevent flying out over the cliff edges and flocks of swallows are active during the day at the rim edge, affording another efficient barrier to transcanyon gene flow.

There is no obvious indication that habitats of the two rims differ.

Fig. 2. (opposite page). Protocol of Arphia conspersa populations and locality elevations.

${ }^{3}$ Elevations are estimated from the following $7 \quad 1 / 2$ minute U.S. Geologic Survey topographic maps: Black Ridge, Red Rock Canyon, Mt. Gunnison, Cathedral Peak, Curecanti Needle, Grizzly Ridge, X Lazy F Ranch, Sapinero, and Little Soap Park.

${ }^{4}$ This is the true Blue Mesa Summit east of Blue Creek on U.S. Highway 50 .

${ }^{5}$ Several dilute orange and pink-winged specimens were observed or captured, although no yellow-winged individuals were recorded. 
Locality Elevation ${ }^{3}$ Sample Size \% Orange Sampling in Feet $(\mathrm{n})=(\%)=$ Sample Date No. Orange below 100

\begin{tabular}{|c|c|c|c|c|c|c|}
\hline \multirow[t]{3}{*}{1.} & \multirow{3}{*}{ West of Red Rock Canyon } & 6450 & \multicolumn{2}{|l|}{11} & \multirow{3}{*}{$\begin{array}{l}(100) \\
(100) \\
(100)\end{array}$} & \multirow{3}{*}{$\begin{array}{l}17-\mathrm{VI}-66 \\
17-\mathrm{VI}-66 \\
17-\mathrm{VI}-66\end{array}$} \\
\hline & & 6250 & 14 & & & \\
\hline & & 6400 & 62 & & & \\
\hline 2. & Warner Point & $8100-8300$ & 11 & $(8)$ & $(73)$ & $19-\mathrm{VI}-66$ \\
\hline 3. & Sunset View & 8200 & 172 & $(60)$ & 35 & $19-V I-66$ \\
\hline \multirow{3}{*}{$\begin{array}{l}4 . \\
5 .\end{array}$} & Monument Headquarters & 7950 & 223 & $(75)$ & 34 & $16-V I-66$ \\
\hline & Devils Look Out to & & & & & \\
\hline & Cross Fissures View & 7900 & 160 & $(57)$ & 36 & $28-V I-65$ \\
\hline 6. & Gunnison Point & 8200 & 91 & (20) & $(22)$ & $28-V I-65$ \\
\hline \multirow[t]{5}{*}{7.} & Campground - South Rim & $8300-8400$ & 209 & (43) & 21 & $28-V I-64$ \\
\hline & & & 184 & (54) & 29 & $23-V I-65$ \\
\hline & & & 199 & $(47)$ & 24 & $21-V I I-65$ \\
\hline & & & 296 & (66) & 22 & 14-VI-66 \\
\hline & & & 65 & (18) & $(28)$ & $30-\mathrm{VI}-66$ \\
\hline 8. & $\begin{array}{l}\text { Between Campground and } \\
\text { E. Portal Canyon }\end{array}$ & 8400 & 83 & (7) & $(8)$ & $30-V I-66$ \\
\hline \multirow[t]{2}{*}{9.} & Head of East Portal & 8600 & 59 & (1) & (2) & $21-$ VII- 65 \\
\hline & Canyon & & 187 & (12) & 6 & $15-\mathrm{VI}-66$ \\
\hline 10. & East Portal at River & $6500-7000$ & 12 & (2) & $(17)$ & $19-\mathrm{VI}-66$ \\
\hline 11. & Coffee Pot Hill & 8750 & 315 & (24) & 8 & $25-V I-66$ \\
\hline 12. & Poverty Mesa & 9500 & 131 & (5) & 4 & $25-V I-66$ \\
\hline 13. & Sheep's Knob & 9400 & 225 & (1) & $<1$ & $27-V I-66$ \\
\hline 14. & Cerro Summit & 7900 & 89 & (3) & (3) & $23-V I-64$ \\
\hline \multirow[t]{2}{*}{15.} & Rt. $50-$ School house & & & & & \\
\hline & Dist. \# 9 & 7100 & 67 & $(0)$ & $(0)$ & 8-VII-65 \\
\hline 16. & W. Fitzpatrick Mesa & 9100 & 123 & $(0)$ & 0 & 2 -VII-66 \\
\hline 17. & E. Fitzpatrick Mesa & 8400 & 49 & (3) & (6) & $2-$ VII-66 \\
\hline 18. & Blue Mesa Summit ${ }^{4}$ & 8200 & 159 & (14) & 9 & $27-V I-65$ \\
\hline 19. & Green Mt. Reservoir & 7900 & 12 & (12) & $(100)$ & $28-V I-66$ \\
\hline 20. & E. Green Mt. & 8200 & 23 & (23) & $(100)$ & $25-V I-66$ \\
\hline 21 . & Serpent Pt. Meadow & 8000 & 46 & $(46)$ & (100) & $23-V I-66$ \\
\hline 22. & North Rim Campground & 7800 & 48 & $(48)$ & $(100)$ & $25-V I-64$ \\
\hline \multirow[t]{2}{*}{23.} & Grizzly Gulch & 7700 & 41 & $(41)$ & (100) & $25-V I-64$ \\
\hline & & & 91 & (91) & $(100)$ & $30-V I-65$ \\
\hline 24. & Narrows Overlook & 7900 & 88 & (88) & $(100)$ & $30-V I-65$ \\
\hline \multirow[t]{2}{*}{25 . } & Rangers Station - N. Rim & 8000 & 371 & (371) & 100 & $30-V I-65$ \\
\hline & & & 288 & $(288)$ & 100 & $22-\mathrm{VI}-65$ \\
\hline 26. & Dead Horse Gulch & 8250 & 188 & $(188)^{5}$ & 100 & $23-24-V I-66$ \\
\hline 27 . & Dead Horse Mesa & 8500 & 209 & $(209)^{5}$ & 100 & $25-\mathrm{VI}-66$ \\
\hline \multirow[t]{2}{*}{28.} & Spring Gulch & 7800 & 108 & $(108)^{5}$ & 100 & 7 -VII-65 \\
\hline & & & 262 & $(261)$ & $>99$ & $26-V I-66$ \\
\hline 29. & Pine Ridge & $8200-8400$ & 125 & $(125)^{5}$ & 100 & $27-V I-66$ \\
\hline 30. & $\begin{array}{l}\text { Buckhorn Gulch } \\
\text { at Rt. } 92\end{array}$ & $8200-8400$ & $\begin{array}{l}142 \\
101\end{array}$ & $\begin{array}{c}(138) \\
(99)\end{array}$ & $\begin{array}{l}97 \\
98\end{array}$ & $\begin{array}{l}\text { 7-VIII-65 } \\
\text { 27-VI-66 }\end{array}$ \\
\hline 31. & $\begin{array}{l}\text { Old Black Mesa Road } \\
\text { NFS boundary North }\end{array}$ & 8300 & 108 & (91) & 84 & $25-V I-64$ \\
\hline 32. & $\begin{array}{l}\text { Mesa Creek } \\
\text { Black Mesa Road Ict. }\end{array}$ & 9600 & 126 & (35) & 28 & $29-V I-64$ \\
\hline 33. & Myers Gulch Road & 9400 & 107 & (4) & 4 & $29-V I-64$ \\
\hline & Curecanti Ck at Rt. 92 & 8000 & 58 & (1) & (2) & $28-V I-64$ \\
\hline \multirow[t]{2}{*}{35.} & Pioneer Lookout & 8000 & 6 & $(0)$ & $(0)$ & 7 -VII- 64 \\
\hline & & & 18 & (0) & (0) & 1-VII-66 \\
\hline 36. & Haypress Gulch & 8000 & 71 & (4) & (6) & $28-V I-64$ \\
\hline 37. & Sapinero Guard Stn. & 7800 & 231 & (63) & 27 & $27-V I-65$ \\
\hline 38. & Soap Ck. Campground & 7700 & 79 & (3) & (4) & 6-VII- 64 \\
\hline 39. & Little Soap Park & 8000 & 166 & $(0)$ & 0 & 6-VII-64 \\
\hline 40. & Sapinero at Rt. 50 & 7600 & 139 & (118) & 85 & $27-V I-65$ \\
\hline
\end{tabular}


They are equivalent in elevation, climate and biotic community structure, and are separated by no more than one mile of horizontal space. Nor does the wing-color of $A$. conspersa appear to be influenced by external factors such as humidity, extremes of temperature, etc. Since homogeneous populations of both colors are found in equivalent habitat and climatic extremes elsewhere, ontogenetic and selective hypotheses seem unlikely, although untested experimentally. The wings are kept folded during courtship and the female has no opportunity to see the color of the male's wings; therefore, sexual selection is not likely during the ground interaction, at least. There is, of course, the possibility that color is accompanied by some other trait for wing color pleiotropically determined genetically with some behavioral effects which could have sexual selective value.

As hypothesis alternative to one which assumes selective differences in the two areas supposes that these populations represent partially arrested introgression of two formerly distinct geographic variants which reached the Black Canyon after it had acquired much its present form. It is not yet clear to us what might have caused the homogeneity and isolation of the variant populations - if a polymorphic species was indeed the progenitor. However, our mapping of the populations throughout the Gunnison Basin has shown a large orange-winged population centered near Grand Mesa and the Elk Mountains and a homogeneous yellow-winged population centered in the San Juan Mountains. The analysis of the zoogeography of this species in the Gunnison Basin soon will be completed. Perhaps the heavy Pleistocene glaciation of the area (Richmond, 1965) may hold a clue to the origin of these populations, but such slow speed of gene flow since then may well be due to the slow rate of dispersal the low vagility of the species due to the combination of social attraction and relatively restricted habitat preference.

Whatever the origin of the homogeneous populations, the barrier of the Black Canyon of the Guninson River evidently acts as a finemeshed filter with discontinuous habitats scattered infrequently over a spectacularly difficult terrain. The "insularized" populations may also reach their reproductive peaks at different times due to the seasonal effect of altitude on their phenology. Barring undetected selection factors such as predator preference for the rare variant, a filter effect could work multidimensionally to prevent thorough introgression of these two variants.

\section{SuMMARY}

The Black Canyon of the Gunnison River in Colorado may be a nearly complete barrier to direct gene flow between populations of the oedipodine grasshopper, Arphia conspersa. In this species, a con- 
venient marker (wing color) is available which may have been segregated in the source populations elsewhere in the Gunnison Basin during the Pleistocene. The evidence is circumstantial that the northern orange and southern yellow populations reached the Black Canyon area after the canyon had acquired its present form. The clinal variation between demes of the South Rim may be due to southward gene flow of orange-wing across the river at the western end of the canyon and slow lateral movement along the rim. The slow speed of gene flow seems to be due to the sedentary behavior of the adults, spatial discontinuities in suitable habitat and seasonal differences between the rims and the river $2000 \mathrm{ft}$. below.

Acknowledgements.

We are grateful for the aid of David Werner, Darelyn Weber, Ruth Lewert, Allen Berlind, and Joyce Redemske, our assistants for at least one of the years of study; the Rangers of the National Park Service, particularly Jack Fewlass, Wilton Hoy and Supt. Henry During; and the ranchers who gave us information and permission to enter their land for this study, particularly Joseph Eisaguirre, John Leonard, Octave Nicholas, Clarence Sanburg, Milton Sanburg, and Russell Sanburg. We thank James Seery, Project Construction Engineer for the Bureau of Reclamation, for allowing us access to East Portal while construction for Crystal Dam was still underway. Wallace R. Hansen of the U. S. Geological Survey offered helpful suggestions on the format and background of Plate 7 and kindly gave us permission to modify Fig. I 5 of Geological Survey Bulletin II9I for Fig. I of this paper. We would also like to thank Dr. Eliot Spiess who read the manuscript and offered constructive criticism.

This work was supported in part by grant GB-220I of the National Science Foundation, grants from the Research Board of the University of Illinois, and a Sigma Xi-RESA Grant-in-Aid of Research for the summer of 1963.

\section{Literature Cited}

Allee, W. C., A. E. Emerson, O. Park, T. Park, and K. P. Schmidt.

1949. Principles of Animal Ecology (Philadelphia: W. B. Saunders Company).

Hall, E. R. AND K. R. Kelson.

1959. The Mammals of North America, Vol. I (New York: The Ronald Press Company).

HANSEN, W. R.

1962. The Black Canyon of the Gunnison, Today and Yesterday. U. S. Geol. Surv. Bull. 1191.

Richmond, G. M.

1965. Glaciation of the Rocky Mountains. In Wright, H. E. and D. G. Frey (Editors), The Quaternary of the United States (Princeton, New Jersey: Princeton University Press, p. 217-230). 

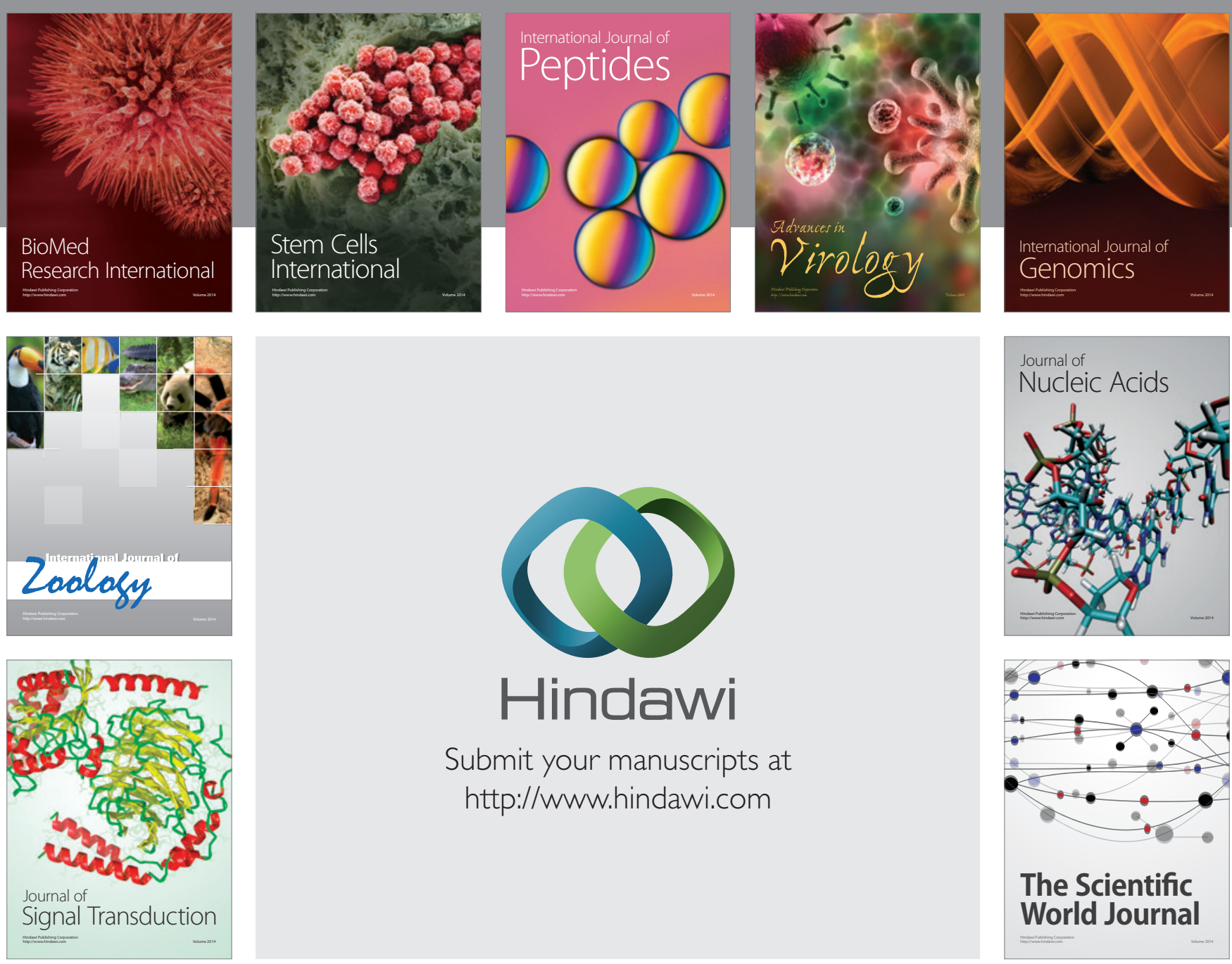

Submit your manuscripts at

http://www.hindawi.com
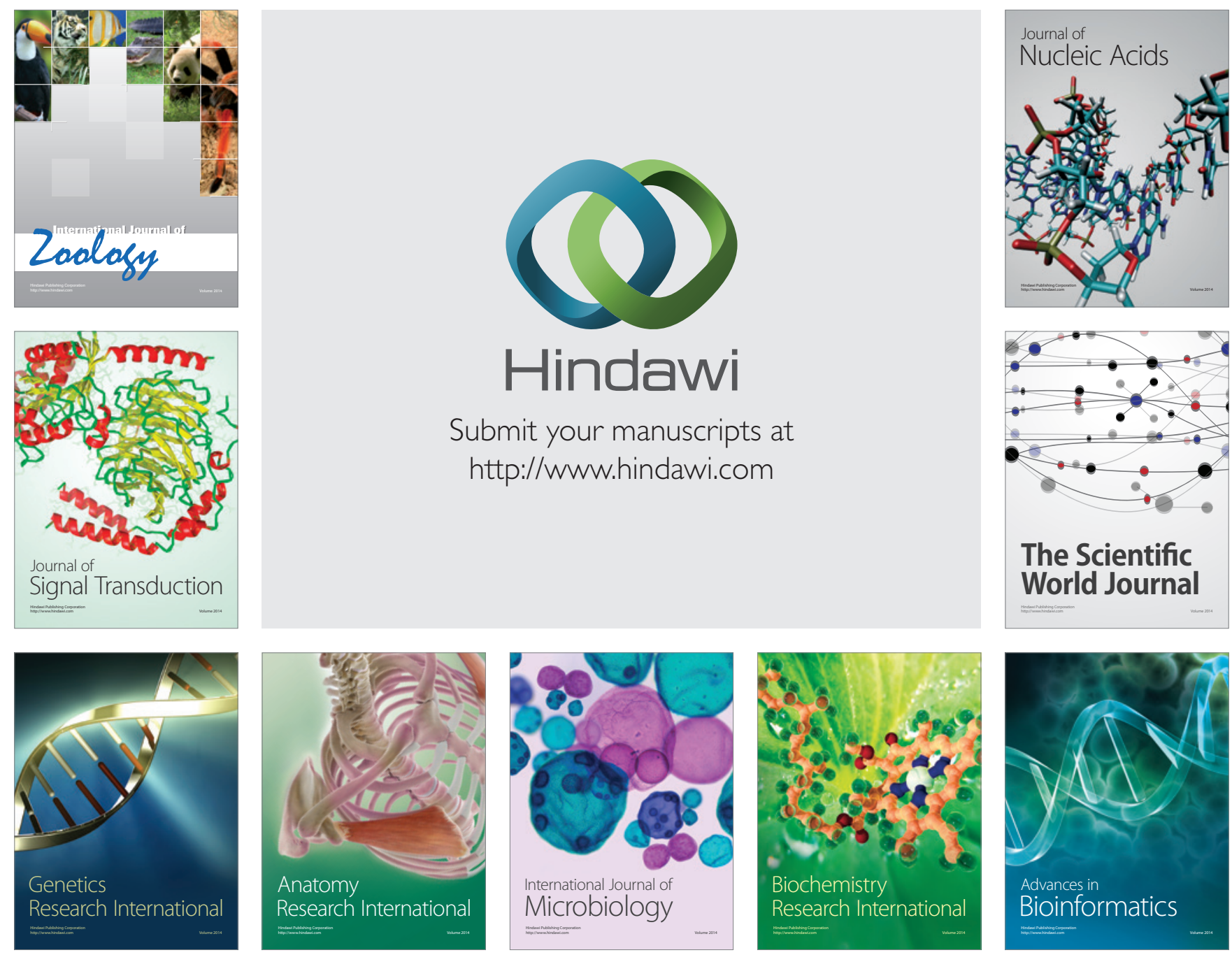

The Scientific World Journal
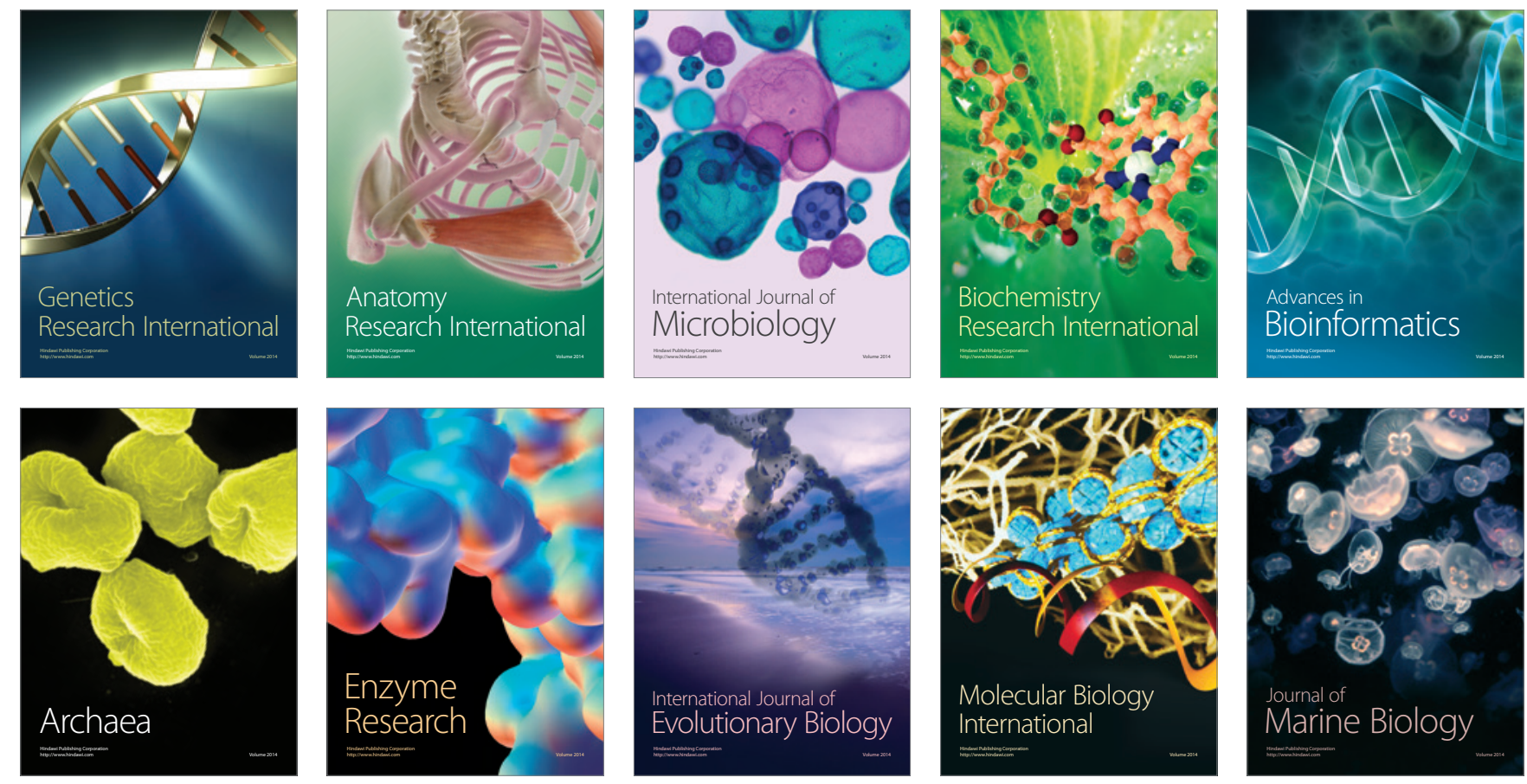